\title{
F--INDUCED CHANGES AND ITS REVERSAL BY ITP IN MEMBRANE TURBIDITY AND ADENYLATE CYCLASE ACTIVITY OF CHICK BRAIN MICROSOMES
}

\author{
Takeo ASAKAWA and Hiroshi YOSHIDA \\ Department of Pharmacology I. Osaka Uniwersity School of Medicine, \\ Kita-ku, Osaha 530, Japan
}

Accepted January 12. 1976

\begin{abstract}
The activation of adenylate cyclase by $\mathrm{NaF}$ was dependent on the previous incubation time and the concentration of $\mathrm{F}^{-}$. The activation by $\mathrm{F}^{-}$was irreversible and $\mathrm{Mg}^{2+}$ was required for the maximum effect. Turbidity of microsome suspension was also greatly increased by $\mathrm{F}^{\prime \prime}$ plus $\mathrm{Mg}^{\prime \prime}$. These cffects on adenylate cyclase and membrane turbidity were specific for $\mathrm{F}^{--}$and $\mathrm{F}^{-}$-salluration curves for both were similar, though $\mathrm{Mg}^{2}$-saturation curves for both were dissimilar. The increase in turbidity induced by $\mathrm{F}^{-}$plus $\mathrm{Mg}^{2}:$ was rapidly reversed by ATP, GTP, ITP, UTP and CTP. However, ITP only, among all the triphospho-nucleotides tested, reversed the activity of adenylate cyclase previously activated by $\mathrm{NaF}$ plus $\mathrm{MgCl}_{2}$. The activity of the cncyme reversed by ITP was not, however, re-enhanced by the presence of $\mathrm{NaF}$ in the assay medium. These results suggest the possibility that $\mathbf{F}$ - induces a change in the membrane structure itself, and this change can be reversed by incubation with ITP. Consequently, adenylate cyclase may be confomed either to an activated or an unactivated state.
\end{abstract}

It is acknowledged that cyclic AMP is an important metabolic regulator and a mediator of hormone actions in a wide variety of tissues. Adenylate cyclase locates in a particulate fraction and is stimulated by $\mathrm{NaF}$ and various hormones in many tissues. Stimulation of this enzyme by NaF was originally reported by Rall and Sutherland (1) and Sutherland et al (2). Although the mechanism of stimulation of adenylate cyclase by NaF is unknown, recently some properties of stimulating effects of NaF have been reported $(3,4)$. Stimulation of adenylate cyclase by $\mathrm{VaF}$ is apparently nonspecific and differs from that by hormones. $\mathrm{NaF}$ stimulates adenylate cyclase activity only in a broken cell preparation, and does not do so in intact cells of many tissues (5) including central nervous system (6). The stimulating cfiect of hormones is reversible (7), whereas the stimulating effect of $\mathrm{NaF}$ is not reversed on the enzyme from parotid glands (8), adrenal cortex $(9,10)$, rat cerebral cortex (11) and skeletal muscles (12). However, the effects of $\mathrm{NaF}$ and hormones on adenylate cyclase may nol be completely independent. Combinations of $F^{-}$with hormones do not yield additive activities. Harwood and Rodbell (13) have suggested that $\mathrm{NaF}$ acts at some point on the pathway by which hormonal interaction with the receptor leads to an increase in the catalytic activity of adenylate cyclase. Recently Naijar and his co-workers (14-16) hypothesized on the mechanism of activation of adenylate cyclase by $\mathrm{F}^{-}$and evidence which supports their hypothesis was seen in the adenylate cyclases from polymorphonuclear granulocytes and blood platelets. 
In.our previous studies $(17,18)$, young chicks were used to elucidate the effects of cyclic AMP, biogenic amines and prostaglandins on the central nervous system. We favored young chicks rather than mammals as experimental animals as it was possible to show the remarkable effects of cyclic AMP on locomotor activity quantitatively, and to observe that remarkable effects began to appear in $20 \mathrm{sec}$ to one min after intracerebral administration.

As a continuation of this work, we studied the NaF-stimulated adenylate cyclase of chick brains. Preliminary accounts of this work have already appeared $(19,20)$.

\section{MATERIAIS AND METHODS}

\section{Preparation}

Two week-old male White Leghorn chicks were decapitated. Telencephalones were removed and homogenized in 5 vol. of the homogenizing medium which contained the following components in the final concentration indicated; $100 \mathrm{mM} \mathrm{Na-glutamate,} 10 \mathrm{mM}$ $\mathrm{MgCl}_{2}, 20 \mathrm{mM} \mathrm{NaH} \mathrm{mO}_{4}$ and $0.1 \mathrm{mM}$ GTP. The $\mathrm{pH}$ of the solution was adjusted to 7.0 with $\mathrm{NaOH}$. The homogenate was centrifuged at $2,500 \times \mathrm{g}$ for $15 \mathrm{~min}$. The supernatant obtained was centrifuged at $77,500 \times \mathrm{g}$ for $40 \mathrm{~min}$. The precipitate was washed once with the same medium by centrifugation. The final pellets were suspended in the same medium and kcpt at $-20^{\circ} \mathrm{C}$ (designated $\mathrm{Mic}$.). Under this condition, adenylate cyclase activity was stable for more than two months. This fraction was observed to contain mostly microsomelike vesicles with a slight contamination of mitochondria as seen under electron microscopy.

Prior to use, this sample (Mic) was centrifuged at $77,500 \times \mathrm{g}$ for $40 \mathrm{~min}$ and the precipitate was washed nnce by resuspension and centrifugation in $20 \mathrm{mM}$ Tris $\mathrm{HCl}$ buffer $(\mathrm{pH} 7.35)$. The pellets were suspended in $20 \mathrm{mM}$ Tris $\mathrm{HCl}$ buffer $(\mathrm{pH} \mathrm{7.35)}$ and used for experiments on adenylate cyclase.

For studies on turbidity changes, Mic fraction was dialyzed against 100 vol. of $60 \%$ saturated $\left(\mathrm{NH}_{4}\right)_{2} \mathrm{SO}_{4}(\mathrm{pH} 8.8)$ containing $0.1 \mathrm{~m} . \mathrm{M}$ EDTA at $0{ }^{\circ} \mathrm{C}$ for $3 \mathrm{hr}$ and then centrifuged at $9,000 \% \mathrm{~g}$ for $15 \mathrm{~min}$. The pellets were washed 3 times with $20 \mathrm{mM}$ Tris $\mathrm{HCl}$ buffer (pH 7.35) by centrifugation. The final pellets were resuspended in $20 \mathrm{mM}$ Tris $\mathrm{HCl}$ buffer (pH 7.35) (designated Washed $\mathrm{Mic}$ ) and used for experiments on turbidity changes. After the treatment with alkaline $\left(\mathrm{NH}_{4}\right)_{2} \mathrm{SO}_{4}$, turbidity was always increased to the same plateau by the addition of $\mathrm{NaF}$ and $\mathrm{MgCl}_{2}$. But before the treatment with alkaline $\left(\mathrm{NH}_{4}\right)_{2} \mathrm{SO}_{4}$, turbidity was increased to a maximum and then rapidly decreased by adding $\mathrm{NaF}$ and $\mathrm{MgCl}_{2}$. The maximum level varied from one experiment to another under the same condition.

Treatment with alkaline $\left(\mathrm{NH}_{4}\right)_{2} \mathrm{SO}_{4}$ resulted in approximately a $30 \%$ loss in adenylate cyclase activity.

Adenylate cyclase activity

Adenylate cyclase activity was measured by the method of Krishna et al (21) with the modification by Perkins and Moore (11). Lnless otherwise noted, the standard assay medium (in a total vol. of $1.0 \mathrm{ml}$ ) contained the following components in the final concentration indicated; 40) $\mathrm{mM}$ Tris HCl buffer (pH 7.35). $4 \mathrm{mM} \mathrm{MgCl}, 8 \mathrm{mM}$ theophylline, $5 \mathrm{mM}$ phospho(enol)pyruvate, 125 , ge per $\mathrm{ml}$ of pyruvate kinase (including 10 , ymoles of $\left(\mathrm{NH}_{4}\right.$ ): 
$\left.\mathrm{SO}_{4}\right) 0.8 \mathrm{mM}$ cyclic AMP, $0.4 \mathrm{mM}\left[{ }^{3} \mathrm{H}\right] \mathrm{AMP}(5.2, " \mathrm{Ci}$ per mole) and the enzyme sample (usually $0.4-0.9 \mathrm{mg}$ protein). The assay medium was incubated at $30^{\circ} \mathrm{C}$ for $20 \mathrm{~min}$ and then placed in a boiling water bath for 5 min. In a control reaction $\left[{ }^{3} \mathrm{H}\right] \mathrm{ATP}$ was added, after boiling for $5 \mathrm{~min}$, to the tube containing all of the components except [3H]ATP. The tube was then re-placed in the boiling bath for 5 min. After cooling in ice, the samples were centrifuged to remove heat-denatured protein. The supernatant fluid was transferred to Dowex $50 \mathrm{~W}-\mathrm{X} 8$, mesh 100-200, column $(1.0 \mathrm{ml}$ of column vol.). Elution of cyclic AMP from the column was as described by Krishna el al (21). Carrier ATP (2//moles) was added to the $3.5 \mathrm{ml}$ of cyclic AMP fraction. After $\mathrm{Zn}(\mathrm{OH})_{2}-\mathrm{BaSO}_{4}$ precipitation, a portion of the supernatant fluid was analyzed for radioactivity with Brays solution (22) and another used to determine the absorbance at $260 \mathrm{ml} \%$. which provided a measure for the recovery of cyclic AMP throughout the entire procedure. The enzyme activity was linear with time for 25-30 min. In tables and figures, the values of adenylate cyclase activity are corrected for recovery and expressed as nanomoles of cyclic AMP formed in $20 \mathrm{~min}$ per $\mathrm{mg}$ of protein at $30^{\circ} \mathrm{C}$. All assays were performed in duplicate.

Turbidity changes

Washed Mic sample was incubated with $\mathrm{NaF}$ (test ions) and $\mathrm{MgCl}_{2}$ in $20 \mathrm{mM}$ Tris $\mathrm{HCl}$ buffer $(\mathrm{pH} 7.35$ ) at $30 \mathrm{C}$. Turbidity changes were estimated by recording O.D. at $660 \mathrm{~m} / \mathrm{h}$ continuously. After preincubation at $30^{\circ} \mathrm{C}$, the reaction was started by adding $\mathrm{NaF}$ and $\mathrm{MgCl}_{2}$ simultaneously or by adding Washed Mic samples. A decrease in O.D. at $660 \mathrm{~m} / \%$ due to dilution was corrected.

Protein was determined by the method of Lowry cl al. (23) with bovine serum albumin as a standard.

\section{Chemicals}

Cyclic AMP was a gift from Takeda Pharmaceutical Co., Ltd. [ $\left.{ }^{3} \mathrm{H}\right] \mathrm{ATP}$ was obtained from New England Nuclear Corp. ATP, GTP (Type II-S), ITP, UTP, CTP, ADP, IDP, pyruvate kinase (type I) and phospho(enol)pyruvate were purchased from Sigma Chemical Co. Other reagents used were all commercial products of analytical grade.

\section{RESULTS}

The activation of adenylate cyclase and the turbidity changes of microsome suspension induced by $F^{-}$and $M g^{2+}$

The enzyme was previously incubated with $\mathrm{F}^{-}$and $\mathrm{Mg}^{2+}$ in $20 \mathrm{mM}$ Tris $\mathrm{HCl}$ buffer $(\mathrm{pH} 7.35)$ at $30^{\circ} \mathrm{C}$ and the enzyme activity was measured with 10 times dilution in the absence of $\mathrm{F}^{-}$(Fig. 1). The activity increased with the time of the previous incubation and was higher than that of untreated enzyme measured with $\mathrm{F}^{-}$in the assay medium. When the enzyme was previously incubated with $\mathrm{F}^{-}$and $\mathrm{Mg}^{2+}$ at $30^{\circ} \mathrm{C}$ for $30 \mathrm{~min}$ and thoroughly wished with Tris HC'I bufler (p) 7.35) by repeated centrifugation, it showed a high atetivity without a addition of $F$. The activity was not further enhanced by adding $F^{-10}$ the assay nedium (Fig. 1, inserted graph). 


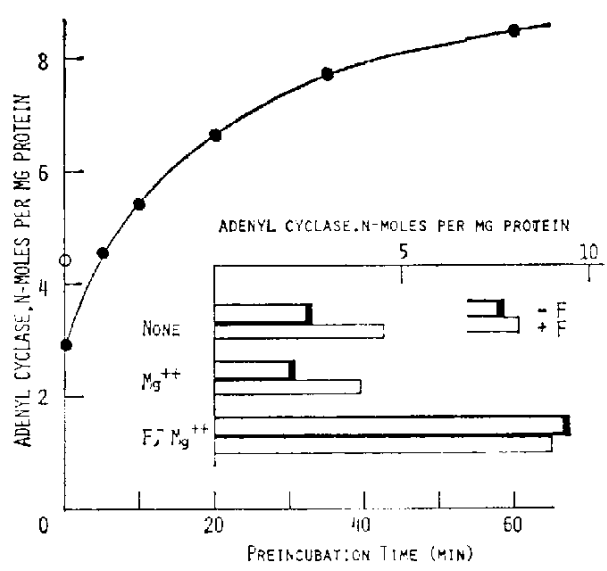

Fici. 1. Activation of adenylate cyclase by the previous incubation with $\mathrm{NaF}$ and $\mathrm{MgCl}$. The enzyme preparation $16.25 \mathrm{mg}$ of protein per ml) was incubated at $30 \mathrm{C}$ in the presence of $4.0 \mathrm{mM} \mathrm{NaF}$ plus $4.0 \mathrm{mM}$ $\mathrm{MgCl}_{2}$. The incubation was started by adding $\mathrm{NaF}$ and $\mathrm{MgCl}_{2}$ and at the time indicated $0.1-\mathrm{ml}$ aliauots were withdrawn and added to the assay medium (a final vol. of $1.0 \mathrm{ml}$ ) for measurement of adenylate cyclase activity in the absence of Nat. The activity at the zero time was measured in the presence ( ) and absence (O) of $4.0 \mathrm{mM} \mathrm{NaF}$. In the inserted graph, the enzyme preparations $10.32 \mathrm{mg}$ of protein per $\mathrm{ml}$ ) were incubated in the presence of either $4.0 \mathrm{mM} \mathrm{NaF}$ plus 4.0 $\mathrm{mM} \mathrm{MgCl}_{2}\left(\mathrm{~F}, \mathrm{Mg}^{2}\right.$ ) or $4.0 \mathrm{~m} \mathrm{M} \mathrm{MgCl}$ : only $\left(\mathrm{Mg}^{2}\right)$, or in the absence of $\mathrm{VaF}$ and $\mathrm{MgCl}_{2}$ (Nonc). After incubation at $30 \mathrm{C}$ for 30 min the enzyme preparations were washed twice with $20 \mathrm{mM}$ Trsi $\mathrm{HCl}$ buffer (pH 7.35) by centrifugation. The find pellets were assayed for adenylate cyclase activity in the persence and absence of $4.0 \mathrm{mM} \mathrm{NaI}$. Valucs represent the average from duplicate incubations.

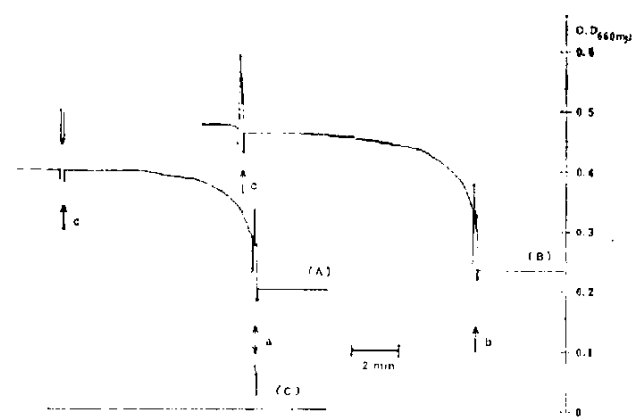

Fici. 2. Effect of NaF and $\mathrm{MgCl}$ on the lurbidity of microsome suspensions. Turbidity changes were examined by measurement. of O.D. at $660 \mathrm{~m} !$ !. Washed Vic samples (75, $\mathrm{g}$ of protein per $\mathrm{ml}$ ) were incubated at $30 \mathrm{C}$ in $20 \mathrm{mM}$ Tris $\mathrm{HCl}$ buffer (pH 7.35). At the time indicatcd by the arrow a or $b, \mathrm{NaF}$ and $\mathrm{MgCl}_{2}$ were added at $3.5 \mathrm{mM}$ each (A) or $9.3 \mathrm{mM}$ each (B). At the lime indicated by the arrow $c$, the incubation mixtures were stirred. In the absence of washed Mic samples the addition of $\mathrm{NaF}$ and $\mathrm{MgCl}_{2}$ had no effect on O.D. at $660 \mathrm{~m}$ ! (C).

On the previous incubation with $\mathrm{F}^{--}$and $\mathrm{Mg}^{2+}$, turbidity of the enzyme suspension was greatly increased and small fragment-like precipitates were observed. Fig. 2 shows the effect of $\mathrm{F}^{-}$and $\mathrm{Mg}^{2+}$ on turbidity of the microsome suspension (Washed Mic sample). Turbidity was rapidly increased by adding $\mathrm{F}^{-}$and $\mathrm{Mg}^{2+}$ and reached the plateau in about 6 min. When the microsome preparation was denatured by heating at $100 \mathrm{C}$ for 10 min, the increase in turbidity indeced by $\mathrm{F}$ and $\mathrm{M} \mathrm{r}^{2+}$ was not observed. The percent increase in the turbidity Wals dependent on the concentration of protein which had a negative correlation (1 ig. 3).

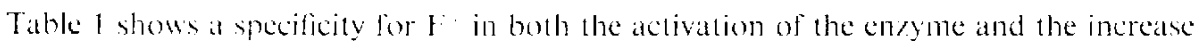




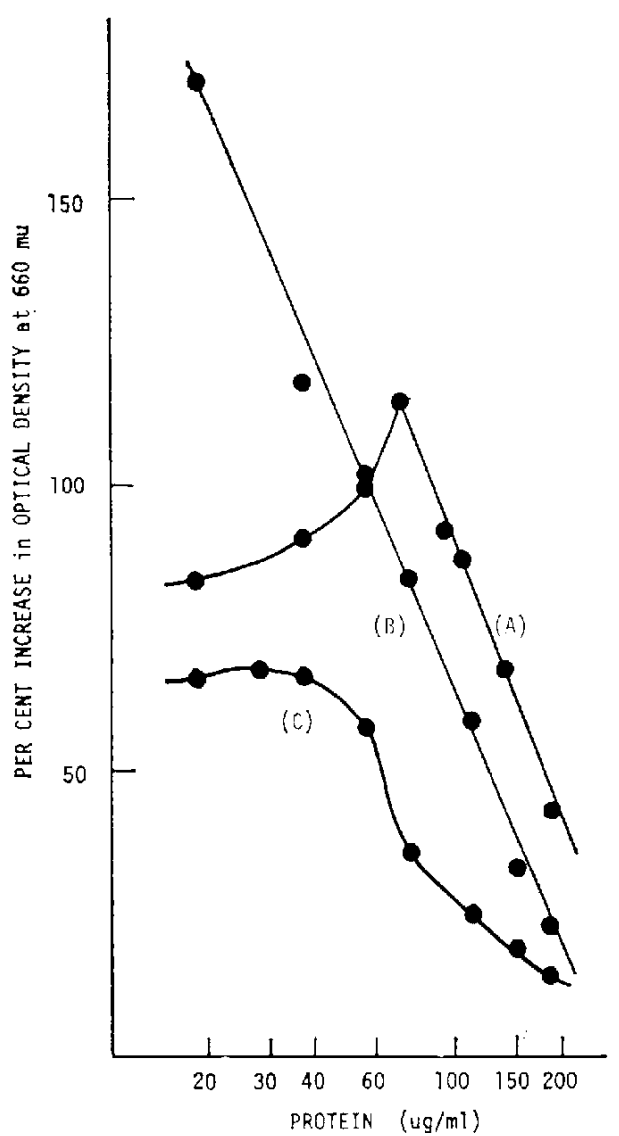

FIG. 3. Effect of the concentration of microsomes on the turbidity change induced by $\mathrm{NaF}$ and $\mathrm{MgCl}_{2}$. Washed $\mathrm{Mic}$ samples were incubated at varying concentrations at $30 \mathrm{C}$ in the presence of $9.3 \mathrm{mM} \mathrm{NaF}$ plus $9.3 \mathrm{mM} \mathrm{MgCl}_{2}$ (A), $3.5 \mathrm{mM} \mathrm{NaF}$ plus $3.5 \mathrm{mM} \mathrm{MgCl}$ (B) or $1.0 \mathrm{mM} \mathrm{NaF}$ plus $1.0 \mathrm{mM} \mathrm{MgCl}_{2}$ (C). The turbidit? change was expressed as percent increase in O.D. at $660 ; \mathrm{m}$. Values represent the average from duplicate incubations.

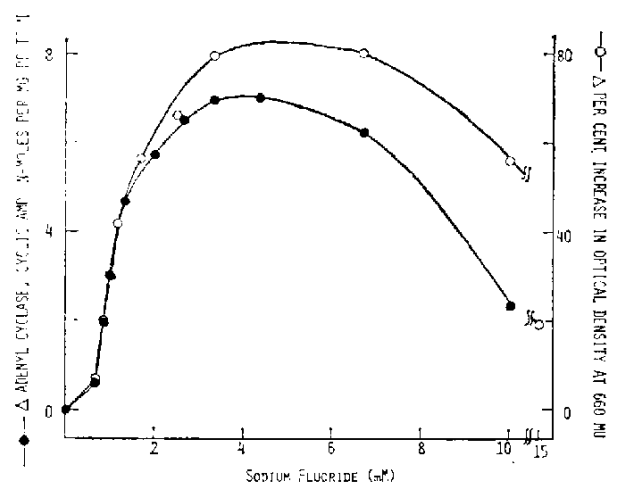

FIci. 4. Activation of adenylate cyclase and the turbidity change of microsomes induced by $\mathrm{MgCl}_{2}$ plus varying concentrations of NaF. The enzyme preparations $(8.0 \mathrm{mg}$ of protein per $\mathrm{ml}$ ) were incubated in the presence of $3.5 \mathrm{mM} \mathrm{MgCl}_{2}$ plus varying concentrations of $\mathrm{NaF}$. After incubation at $30 \mathrm{C}$ for $30 \mathrm{~min}, 0.1-\mathrm{ml}$ aliquots were removed and added to the assay medium for measurement of adenylate cyclase activity $(0-0)$. For measurement of the turbidity change ( :- ) , washed Mic samples (75 $\mu \mathrm{g}$ of protein per $\mathrm{ml}$ ) were incubated at $30 \mathrm{C}$ in the presence of $3.5 \mathrm{mM} \mathrm{MgCl}_{2}$ plus varying concentrations of $\mathrm{NaF}$. Each point indicates the difference in the values obtained with $\mathrm{NaF}$ plus $\mathrm{MgCl}_{2}(3.5 \mathrm{mM})$ and with $3.5 \mathrm{mM} \mathrm{MgCl}$ only. Values represent the average from duplicatc incubations.

in the turbidity. Only fluoride ions produced a strong activation of the enzyme and a great increase in the turbidity. Among various cations, $\mathrm{Li}^{+}$had inhibitory effects both on the turbidity change and on activation of adenylate cyclase caused by $\mathrm{F}^{-}$.

Both the activation of the enzyme and the increase in the turbidity were examined at varying concentrations of $F$. (Fig. 4). The dose-response curves were quite similar and half the maximal effects were obtained at $1.1-1.2 \mathrm{mMF}^{-}$on both the activation and the turbidity change.

Figs. 5 and 6 show the effects of $\mathrm{Mg}^{2+}$ concentration. To examine the effect of $\mathrm{Mg}^{2}$ : concentration on the activation of the anyme. the enzyme preparation was previously 
TABLE 1. Effects of various ions on adenylate cyclase and turbidity of microsome suspensions

\begin{tabular}{|c|c|c|}
\hline & \multicolumn{2}{|c|}{ Relative polency } \\
\hline & Adenylate cyclase & $\begin{array}{l}\text { Optical density } \\
\text { At } 660 \mathrm{mff}\end{array}$ \\
\hline $\mathrm{NaF}$ & $100^{\circ}$ & $100 \%$ \\
\hline $\mathrm{KF}$ & 96 & 100 \\
\hline $\mathrm{NH}_{4} \mathrm{~F}$ & 105 & 94 \\
\hline CsF & 96 & 95 \\
\hline $\mathrm{LiF}$ & 64 & 32 \\
\hline $\mathrm{NaBr}$ & 2 & 9 \\
\hline $\mathrm{Nal}$ & 3 & 0 \\
\hline $\mathrm{NaSCN}$ & 10 & 0 \\
\hline $\mathrm{NaCN}$ & 16 & () \\
\hline $\mathrm{NaNO}_{3}$ & 2 & 0 \\
\hline $\mathrm{NaCl}$ & (0) & (0) \\
\hline
\end{tabular}

Enzyme preparations $(8.6 \mathrm{mg}$ of protein per $\mathrm{ml})$ were incubated in the presence of various ions $(3.5 \mathrm{mM})$ indicated plus $3.5 \mathrm{mM} \mathrm{MgCl}$. After incubation at $30^{\circ} \mathrm{C}$ for $30 \mathrm{~min}, 0.1 \mathrm{-ml}$ aliquots were removed and added to the assay medium for measuremenc of adenylate cyclase activity. In experiments on turbidity changes. washed Mic samples $(75 \mu \mathrm{g}$ of protein per $\mathrm{ml}$ ) were incubated in the presence of varions ions $(3.5 \mathrm{~m}) \mathrm{M}$ indicated plus $3.5 \mathrm{mM} \mathrm{MgCl}$. Both 10 the activation of the enzyme and to the turbidity changes, the potency of $\mathrm{VaF}$ was expressed as $100 \%$ and the potency of $\mathrm{NaCl}$ was expressed as $0 \%$, as Tris $\mathrm{HCl}$ buffer $(\mathrm{pH} 7.35)$ was used in incubation. Values represent the average from duplicate incubations.

incubated with $\mathrm{F}^{-}$plus varying concentrations of $\mathrm{Mg}^{2}$, and washed with Tris $\mathrm{HCl}$ buffer by repeated centrifugation. The activity was then measured in the

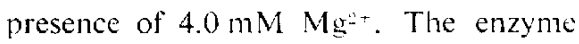
was partially activated by the previous incubation with $\mathrm{F}^{-}$only, as shown in Fig. 6. However, $\mathrm{Mg}^{2+}$ was essential for the turbidity change induced by $\mathrm{F}^{-}$. Half the maximal effects were obtained at 1.6 $\mathrm{mM} \mathrm{M \textrm {g } ^ { 2 + }}$ on the activation of the enzyme and at $1.0 \mathrm{mM} \mathrm{Mg}{ }^{*}$ on the increase in the turbidity.

To examine the effect of a low concontration of $\mathrm{Ca}^{2+}$ on the activity, the enzyme activily was measured in lhe pres-

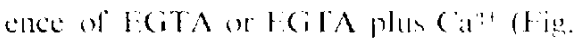
7). In these experiments iwo preparations

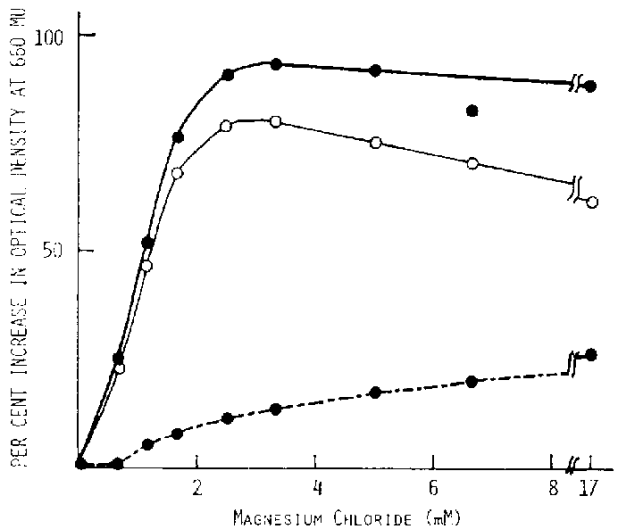

Fici.5. Turbidity change induced by $\mathrm{NaF}$ plus varying concentrations of $\mathrm{MgCl}_{2}$. Washed Mic samples ( $75 \mu \mathrm{g}$ of protein per $\mathrm{ml}$ ) were incubated at $30 \mathrm{C}$ in the presence of $3.5 \mathrm{mM} \vee \mathrm{aF}$ plus varying concentrations of $\mathrm{MgCl}_{2}(-\cdots)$ or $\mathrm{MgCl}_{2}$ only $(-)$. the difference bolween bothcurves. Values represent the aserage from duplicale incubations. of the ename were used; one was the enzyme previously activated by the incubation with 


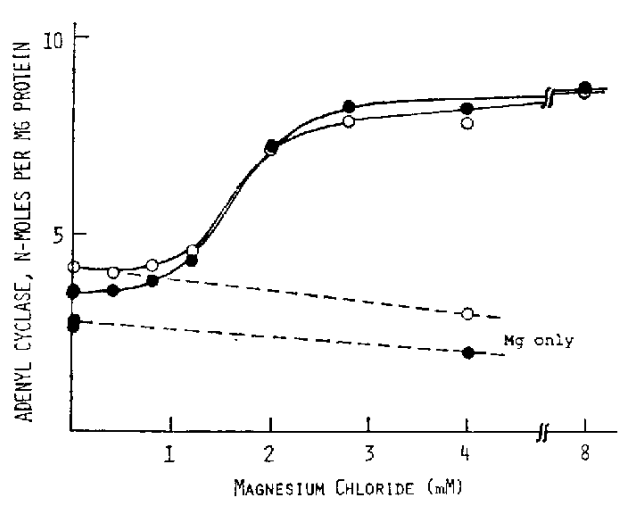

Fig. 6. Activation of adenylate cyclase by $\mathrm{NaF}$ plus varying concentrations of $\mathrm{MgCl}_{2}$. The enzyme preparations $(0.37 \mathrm{mg}$ of protein per $\mathrm{ml}$ ) were incubated in the presence of $4.0 \mathrm{mM} \mathrm{NaF}$ plus varying concentrations of $\mathrm{MgCl}_{2}$. After incubation at $30^{\circ} \mathrm{C}$ for $30 \mathrm{~min}$ the enzyme preparations were washed twice with $20 \mathrm{mM}$ Tris $\mathrm{HCl}$ buffer (pH 7.35) by centrifugation. Adenylate cyclase activity of the final pellets was measured in the standard manner in the presence $(j-3)$ and absence $(\cdots \cdots, \cdot)$ of $4.0 \mathrm{mM} \mathrm{NaF}$. -O, the activity of the enzyme incubated without $\mathrm{NaF}$.

$\mathrm{F}^{-}$, followed by washing, another was the enzyme untreated with $\mathrm{F}^{-}$. On the activity of the latter, the effect of $\mathrm{Ca}^{2+}$ was examined in the presence and absence of $\mathrm{F}^{-}$in the assay medium. As shown in Fig. 7, the presence of EGTA in the assay medium resulted in a marked reduction in the activities of these preparations. Reduction in the activities due to EGTA was completely restored by the simulataneous addition of $\mathrm{Ca}^{2+}$. The maximal activities of these preparations were obtained at a final concentration of $1-3 \times 10^{-6} \mathrm{M}$ free $\mathrm{Ca}^{2+}$ and were slightly higher than those obtained when EGTA was omitted from the assay medium (open circles in Fig. 7).

Studies on the reversibility of the activation and the turbidity change

The increase in turbidity induced by $\mathrm{F}^{-}$and $\mathrm{Mg}^{2+}$ was rapidly reversed by adding ATP

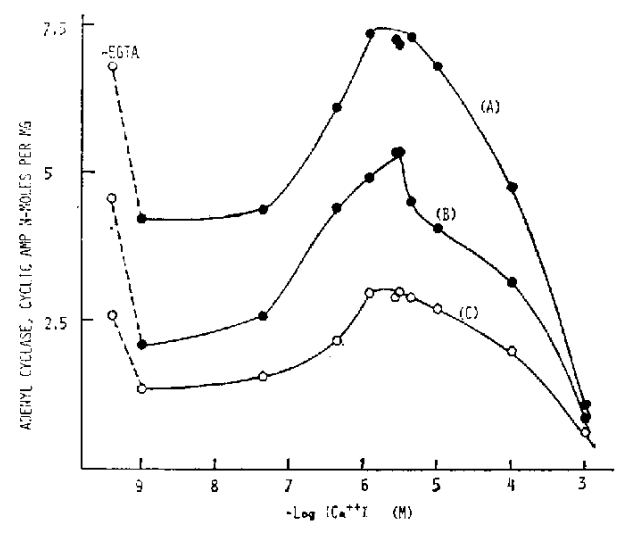

FIG. 7. Effect of $\mathrm{Ca}^{2+}$ on the activity of adenylate cyclase. The activity of adenylate cyclase was measured in the presence of varying concentrations of free $\mathrm{Ca}^{2-}$. Low concentrations of free $\mathrm{Ca}^{2+}\left(10^{-5} \mathrm{M}\right)$ were obtained by adding Ca-EGTA complex (1:1 mole ratio) and EGTA to the assay medium. The concentration of Ca-EGTA plus EGTA was fixed at 0.5 $\mathrm{mM}$. Final concentrations of free $\mathrm{Ca}^{2+}$ in the assay medium containing $4.0 \mathrm{mM}$ $\mathrm{MgCl}_{2}$ at $\mathrm{pH} 7.35$ were calculated by the method of Portzehl et al (24). The points on each curve from left to right $\left(<10^{-5} \mathrm{M}\right.$ $\mathrm{Ca}^{2+}$ ) in figure show the activities measured with (total $\mathrm{Ca}^{2+}$ )/(total EGTA) ratio of 0 , $0.5,0.9,0.99,0.999,0.9999$ and 1.0 . In the expreiments with higher concentrations of $\mathrm{Ca}^{2+}\left(10^{-5}-10^{-3} \mathrm{M}\right), \mathrm{CaCl}_{2}$ was added to the assay medium at the concentrations indicated without EGTA. Curve A indicates the activity of adenylate cyclase which was previously incubated at $30^{\circ} \mathrm{C}$ for $30 \mathrm{~min}$ in the presence of $4.0 \mathrm{mM} \mathrm{NaF}$ plus $4.0 \mathrm{mM} \mathrm{MgCl}_{2}$, and then washed twice with $20 \mathrm{mM}$ Tris $\mathrm{HCl}$ buffer $(\mathrm{pH}$ 7.35 ) by centrifugation. The activity was measured in the absence of $\mathrm{NaF}$ in the assay medium. Curves $\mathbf{B}$ and $\mathbf{C}$ indicate the activity of untreated adenylate cyclase in the presence (B) and absence (C) of $4.0 \mathrm{mM} \mathrm{NaF}$ in the assay medium. . ( $)$ the activity measured in the absence of EGTA. 


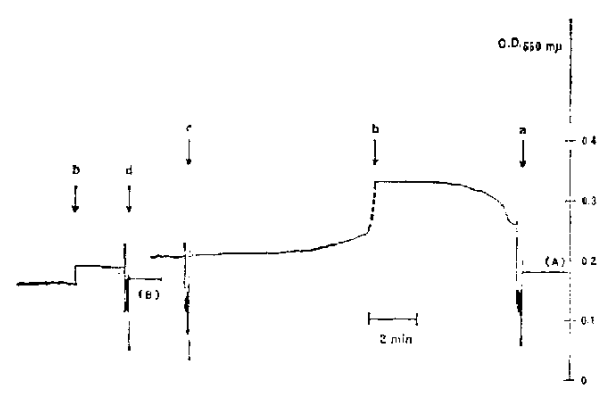

FIG. 8. Effect of ATP on the turbidity change induced by $\mathrm{NaF}$ plus $\mathrm{MgCl}$. Washed $\mathrm{Mic}$ samples $(75 \mu \mathrm{g}$ of protein per $\mathrm{ml})$ were incubated at $30 \mathrm{C}$ in $20 \mathrm{mM}$ Tris $\mathrm{HCl}$ buffer (pH 7.35) (total bo. $2.95 \mathrm{ml}$ ) Al the time indicated by the arrow a or $d$, $\mathrm{NaF}$ and $\mathrm{MgCl}_{2}$ (arrow a) or $\mathrm{MgCl}_{2}$ only (arrow d) were added at $3.5 \mathrm{mM}$ cach. At the time indicated by the arrow $b$, ATP $(0.2 \mathrm{ml}, \mathrm{pH} 7.35)$ was added at 4.3 $\mathrm{mM}$. At the time indicated by the arrow $c$, the incubation mixture was stirred.

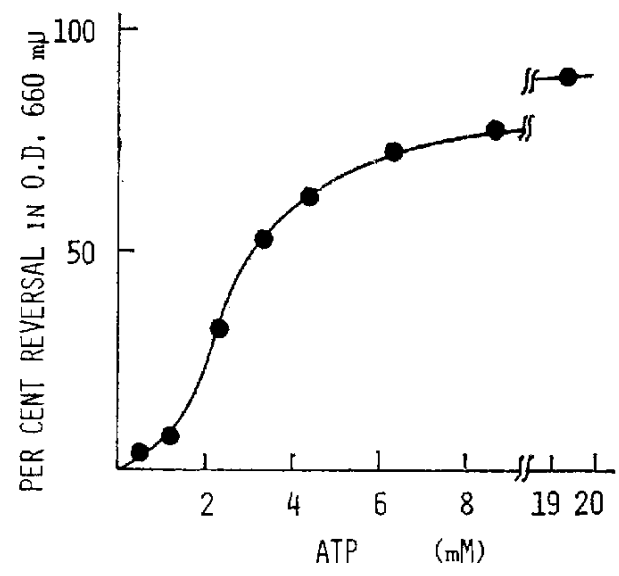

Fic. 9. Effects of varying concentrations of ATP on the turbidity change induced by $\mathrm{NaF}$ plus $\mathrm{MgCl}$. Washed Mic samples (75 $\mu \mathrm{g}$ of protein per $\mathrm{ml}$ ) were incubated at $30 \mathrm{C}$ in the presence of $3.5 \mathrm{mM} \mathrm{NaF}$ p] us $3.5 \mathrm{mM} \mathrm{MgCl}$. After O.D. at $660 \mathrm{mff}$ increased to the plateau. ATP were added to the incubation mixtures at varying concentrations. Percent reversals were calculated from the decreased values in O.D. at $660 \mathrm{~m} \mu$ observed for $4 \mathrm{~min} \mathrm{im}$ mediately after the addition of ATP. values represent the average from duplicate incubations.

(Fig. 8) and the fragment-like precipitates disappeared. The reversal rates were calculated from the decreased value in O.D. at $660 \mathrm{~m} /$ obtained for 4 min immediately after the addition of ATP and expressed as percent of the value in O.D. at $660 \mathrm{~m} /$ increased by $3.5 \mathrm{mM}$ $F$ - plus $3.5 \mathrm{mM} \mathrm{Mg}^{2}{ }^{4}$. The reversal percent plotted as a function of ATP concentration was sigmoid (Fig. 9). Two apparent Kes for ATP appeared on the double reciprocal plots. Fifty percent reversal was obtained at $3.1 \mathrm{mM}$ ATP. ADP and adenosine were less effective than ATP. AMP and Pi were ineffective (Table 2). GTP, ITP, UTP and CTP were as effective as ATP. A high concentration of EDTA had a slight effect. But it showed a different time course and O.D. al $660 \mathrm{~m}$; decreased slowly after addition of EDTA. These results suggested that the triphosphonucleotide itself has a reversing effect on the turbidity change induced by $\mathrm{F}^{-}$and $\mathrm{Mg}^{2}$.

The effect of ATP on the enzyme activated by $F^{-}$was then examined (Table 3 ). The enzyme was activated by the incubation with $4 \mathrm{mM} \mathrm{F}^{-}$and $4 \mathrm{mM} \mathrm{Mg}^{2+}$ in $20 \mathrm{mM}$ Tris $\mathrm{HCl}$ buffer ( $\mathrm{pH}$ 7.35), followed with washing by repeated centrifugation. The activated enzyme was reincubated with $10 \mathrm{mM}$ ATP at 30 C for $15 \mathrm{~min}$. After dialyzing against Tris $\mathrm{HCl}$ buffer ( $\mathrm{pH} 7.35)(10,000$ volumes), the activity was measured both in the presence and in the absence of $\mathrm{F}^{-}$. The reincubation with ATP did not result in a significant change in the activity. However, the activity of the enzyme reincubated with ATP was slightly enhanced 
TABLF. 2. Effects of various nucleotides on the turbidity change induced by NaF plus $\mathrm{MgCl}_{2}$

\begin{tabular}{lcc}
\hline & Concentration & Per Cent Reversal \\
ATP & $4.3 \mathrm{mM}$ & $68.2 \%$ \\
ADP & 4.3 & 47.5 \\
AMP & 4.3 & 7.1 \\
cyclic AMP & 1.2 & $\cdots 6.7$ \\
Adenosine & 4.2 & 33.8 \\
Pi & 2.0 & 1.3 \\
GTP & 4.3 & 54.8 \\
UTP & 4.3 & 66.8 \\
ITP & 4.3 & 62.5 \\
CTP & 4.3 & 66.2 \\
EDTA & 3.2 & -0.9 \\
EDTA & 4.7 & 21.1 \\
\hline
\end{tabular}

Washed Mic samples; $75 \mu \mathrm{g}$ of protein per $\mathrm{ml}$ ) were incubated at $30 \mathrm{C}$ in the presence of $3.5 \mathrm{mM}$ NaF plus $3.5 \mathrm{mM} \mathrm{MgCl}$. After O.D. at $660 \mathrm{~m} \mu$ increased to the plateau, compounds indicated were added to the incubation mixtures. Percent reversals were calculated as for Fig. 9. Values represent the average from duplicate incubations.

TaBLE 3. Effect of ATP on adenylate cyclase previously aclivated by NaF plus $\mathrm{MgCl}_{2}$

\begin{tabular}{|c|c|c|}
\hline \multirow[t]{2}{*}{ Treatment } & \multicolumn{2}{|c|}{$\begin{array}{c}\text { Adenylate cyclase activity } \\
(\mathrm{N} \text {-moles per } \mathrm{mg} \text { protein, } 20 \mathrm{~min})\end{array}$} \\
\hline & $-F^{-}$ & $+\mathrm{F}^{-}$ \\
\hline Without treatment & 3.75 & 7.50 \\
\hline $\begin{array}{l}\text { Incubation with } \mathrm{NaF}+\mathrm{MgCl}_{2} \\
\quad(\mathrm{~F}-\text { Enc) }\end{array}$ & 13.21 & 13.1 \\
\hline $\begin{array}{l}\text { Reincubation with ATP } \\
\text { (ATP-Enz) }\end{array}$ & 14.73 & 16.55 \\
\hline $\begin{array}{l}\text { Reincubation with ATP } \mathrm{Mg}^{2 !-} \\
\qquad\left(\mathrm{ATP}, \mathrm{Mg}^{2--}-\operatorname{Enz}\right)\end{array}$ & 13.00 & 15.00 \\
\hline
\end{tabular}

The enzyme preparations $(0.4 \mathrm{mg}$ of protein per $\mathrm{ml})$ were incubated in the presence of $4.0 \mathrm{mM} \mathrm{NaF}$ plus $4.0 \mathrm{mM} \mathrm{MgCl}$ in $20 \mathrm{mM}$ Tris $\mathrm{HCl}$ buffer ( $\mathrm{pH} 7.35$ ). After incubation at $30 \mathrm{C}$ for $30 \mathrm{~min}$, the enzyme preparations were washed twice with $20 \mathrm{mM}$ Tris $\mathrm{HCl}$ buffer (pH 7.35) by centrifugation. The pellets were suspended in $20 \mathrm{mM}$ Tris HCl bufter ( $\mathrm{pH} 7.35)$ (2.4 $\mathrm{mg}$ of protein per $\mathrm{ml}$ ) $\left(\mathrm{F}^{-}-\mathrm{Enz}\right)$ and further incubated at $30 \mathrm{C}$ for $15 \mathrm{~min}$ in the presence of $10 \mathrm{mM}$ ATP plus $4.0 \mathrm{~m} \mathrm{M} \mathrm{MgCl}_{2}$ (ATP, $\mathrm{Mg}^{2 \div-E n 7 \text { ) }}$ or $10 \mathrm{mM}$ ATP only (ATP Enz). After incubation, these three samples were dialyzed against $20 \mathrm{mM}$ Tris HCI buffer $(\mathrm{pH} 7.35)$ at $4 \mathrm{C}$ for $7 \mathrm{hr}$. Adenylate cyclase activitics were measured in the presence and absence of $4.0 \mathrm{mM} \mathrm{NaF}$. Values represent the average from duplicate incubations.

by $\mathrm{F}^{-}$in the assay medium (Table 3 ). Further, the presence of ATP in the previous incubation with $\mathrm{F}^{-}$and $\mathrm{Mg}^{2+}$ had no significant effect on the activation by $\mathrm{F}^{-}$. When the enzyme previously activated by $\mathrm{F}^{-}$plus $\mathrm{Mg}^{2+}$ was incubated with ATP, the specific activity of the, enzyme sometimes increased due to loss of the protein during the washing. Table 4 shows 
the effect of incubation with various triphospho-nucleotides on the activities of the enzyme previously activated by $\mathrm{F}^{-}$. The enzyme was incubated with $4 \mathrm{mM} \mathrm{F}^{-}$and $4 \mathrm{mM} \mathrm{Mg}^{\circ+}$ in $20 \mathrm{mM}$ Tris $\mathrm{HCl}$ buffer $(\mathrm{pH} 7.35)$ at $30^{\circ} \mathrm{C}$ for $30 \mathrm{~min}$ and then triphospho-nucleotides were added to the incubation mixture. After a further 20 min incubation, the enzyme was washed with Tris HCl buffer ( $\mathrm{pH} 7.35$ ) by repeated centrifugation (nucleotides diluted about 50,000fold). The activity was then measured both in the presence and in the absence of $F^{-}$. Among these triphospho-nucleotides, ITP was quite effective for reversing the activity as shown in Table 4. UTP was less effective. Further the effects of IDP, IMP and inosine were examined (Table 4, Expt. 2) and it was found that only ITP was effective. IDP and IMP had a slight effect. The activity of the enzyme incubated without $\mathrm{F}^{-}$was also reduced by incubation with ITP (Table 4, Expt. 2). As shown in Table 4, the activation of adenylate cyclase by NaF seemed to be completely reversed by ITP, but the enzyme activity reversed by ITP was not enhanced again by adding $\mathrm{NaF}$ to the assay medium. Fig, 10 shows the reversing effect of ITP on the activity at varying concentrations. The activity enhanced by $\mathrm{F}^{-}$was reduced

TABLF 4. Effects of various nucleotides on adenylate cyclase previously activated by $\mathrm{NaF}$ plus $\mathrm{MgCl}_{2}$

\begin{tabular}{|c|c|c|c|}
\hline \multirow{2}{*}{ 1st. Addition } & \multirow{2}{*}{$\begin{array}{l}\text { 2nd. Addition } \\
\text { (10 mM })\end{array}$} & \multicolumn{2}{|c|}{$\begin{array}{l}\text { Adenylate cyclase activity } \\
\text { (N-moles per mg protein, } 20 \mathrm{~min} \text { ) }\end{array}$} \\
\hline & & $\mathrm{F}^{-}$ & $\mathrm{F}$ \\
\hline \multicolumn{4}{|l|}{ Expt. 1} \\
\hline Control (unineubated) & & 3.11 & 5.37 \\
\hline \multirow[t]{6}{*}{$4.0 \mathrm{mM} \mathrm{NaF}-4.0 \mathrm{mM} \mathrm{MgC]_{2 }}$} & None & 11.06 & 10.80 \\
\hline & ATP & 9.72 & 10.98 \\
\hline & GTP & 10.88 & 11.80 \\
\hline & ITP & 4.05 & 4.40 \\
\hline & UTP & 7.57 & 9.21 \\
\hline & CTP & 10.81 & 11.75 \\
\hline \multicolumn{4}{|l|}{ Expt. 2} \\
\hline Control (unincubated) & - & 3.31 & 5.36 \\
\hline \multirow[t]{5}{*}{$4.0 \mathrm{mM} \mathrm{NaF}-4.0 \mathrm{mM} \mathrm{MgClg}$} & No-incubation & 9.34 & 8.37 \\
\hline & ITP & 2.01 & 1.93 \\
\hline & IDP & 5.86 & 5.82 \\
\hline & IMP & 7.15 & 6.73 \\
\hline & Inosine & 8.90 & 7.98 \\
\hline $4.0 \mathrm{mM} \mathrm{MgC1_{2 }}$ only & ITP & 1.82 & 2.05 \\
\hline
\end{tabular}

Enzyme preparations $(0.52 \mathrm{mg}$ of protein per $\mathrm{ml}$ in Expt $1,0.35 \mathrm{~m} g$ of protein per $\mathrm{ml}$ in Expt 2) were incubated in the presence of $4.0 \mathrm{mM} \mathrm{NaF}$ plus $4.0 \mathrm{mM} \mathrm{MgCl}$. After incubation at $30 \mathrm{C}$ for $30 \mathrm{~min}$, nucleotides indicated were added at $10 \mathrm{mM}$ to the incubation mixtures. After further incubation at $30 \mathrm{C}$ for $20 \mathrm{~min}$, the enzyme preparations were washed wice with $20 \mathrm{mM}$ Tris $\mathrm{HCl}$ buffer $(\mathrm{pH} 7.35)$ by centrifugation. The final pellets suspended in $20 \mathrm{mM}$ Tris $\mathrm{HCl}$ buffer $(\mathrm{pH} 7.35$ ), were assayed for adenylate cyclase activity in the presence and absence of $4.0 \mathrm{mM} \mathrm{NaF}$. A different preparation was used for each experiment. Tris $\mathrm{HCl}$ buffer $(\mathrm{pH} 7.35)$ was used in incubation. Values represent the average from duplicate incubations. 


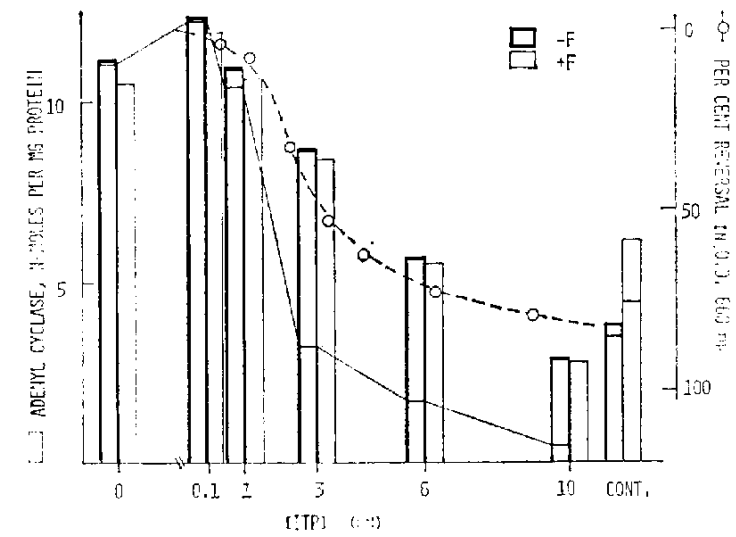

FIs. 10. Effects of varying concentrations of ITP on adenylate cyclase previously activated by NaF plus $\mathrm{MgCl}_{2}$. The experiments on adenylate cyclase were carried out under conditions similar to those described in the legend to Table 4 . The solid line indicates the activity of adenylate cyclase which was kept at $0^{\circ} \mathrm{C}$ for $48 \mathrm{hr}$ after the final pellets were re-suspended. The effec of ITP on the turbidity change induced by $\mathrm{NaF}$ plus $\mathrm{MgCl}_{2}\left(-\ldots . . . \mathrm{r}^{\circ}\right.$ ) was examined under conditions similar to those described in the legend to Fig. 9. Cont. = Activity of untreated enzyme.

with increase in the concentration of ITP. Half the maximal effect was obtained at about $3.5 \mathrm{mM}$ ITP. This value was very similar to that obtained for the reversing effect of ITP on the turbidity enhanced by $\mathrm{F}^{-}$(Fig. 10). The effecl of ITP was also observed on the enzyme sample which was previously incubated with $\mathrm{F}^{-}$and $\mathrm{Mg}^{2+}$ and then washed by centrifugation. The enzyme previously activated by $\mathrm{F}^{-}$was very stable. However, the enzyme which was previously activated by $\mathrm{F}^{-}$and reversed by ITP, was unstable and its activity decreased gradually on standing at $0^{\circ} \mathrm{C}$ (Fig. 10, solid line).

Some incubation systems were tested to observe conditions in which a lower concentration of ITP may reverse the activity previously enhanced by $\mathrm{F}^{-}$. On the enzyme sample which had been treated with $\mathrm{F}^{-}$plus $\mathrm{Mg}^{\prime \prime}$ and then with ATP under the same conditions as for Table 4, a low concentration of ITP $(1 \mathrm{mM})$ was rather effective. Above $50 \%$ of the activity enhanced by $\mathrm{F}$ ' was reversed by further incubation with $1 \mathrm{mM} I T P$ at $30^{\circ} \mathrm{C}$ for $20 \mathrm{~min}$. After treatment with $1 \mathrm{mM}$ ITP, the activity of adenylate cyclase was slightly enhanced $\left(15-20^{\circ}\right)$ by $4.0 \mathrm{mM} \mathrm{NaF}$ in the assay medium.

\section{IDISCLSSION}

Adenylate cyclase of chick brain microsomes was found to be activated by $\mathrm{NaF}$, but was not activated by biogenic amines. The rate of activation by $\mathrm{NaF}$ was dependent on a concentration of $\mathrm{F}^{-}$and $\mathrm{Mg}^{2+}$. Although the enzyme was slightly activated by only $\mathrm{NaF}$ without addition of $\mathrm{Mg}^{2+}, \mathrm{Mg}^{2+}$ was essential for the maximal activation by $\mathrm{F}^{-}$. The activation by $\mathrm{F}^{-}$and $\mathrm{Mg}^{2+}$ was irreversible and was not reversed by dilution, washing or dialysis (Fig. 1, Table 3) of the activated enzyme. Similar observations were originally reported by Perkins and Moore on adenylate cyclase of rat brains (11), and by Schramm and Nain on 
adenylate cyclase of rat parotid glands (8).

Bradham and his co-workers $(25,26)$ reported the implication of a low concentration of $\mathrm{Ca}^{2+}$ in the activity of adenylate cyclase from bovine brains. We obtained similar results on adenylate cyclase of chick brains, and calculated the free $\mathrm{Ca}^{2+}$ concentration required for the maximal activity of adenylate cyclase by using EGTA-Ca ${ }^{2+}$ buffer (24) (Fig. 7). The maximal activities of untreated enzyme measured in the presence and absence of NaF were obtained at a final concentration of $1.3 \cdot 10^{-5} \mathrm{M}$ free $\mathrm{Ca}^{2+}$. Even on the enzyme previously activated by $\mathrm{F}^{-}$and $\mathrm{Mg}^{2+}$, a low concentration of free $\mathrm{Ca}^{2+}\left(1-3>10^{-6} \mathrm{M}\right)$ was required for its maximal activity (Fig. 7). At the optimal concentration of free $\mathrm{Ca}^{2+}$, the activities were slightly greater than those measured in the absence of EGTA.

The turbidity change induced by $\mathrm{F}^{-}$and $\mathrm{Mg}^{2+}$ was dependent on the concentrations of $\mathrm{F}^{-}$and $\mathrm{Mg}^{2+}$ and was specific for $\mathrm{F}$ (Figs. 4 and 5, Table 1). Both the turbidity change of microsomes and the activation of the enzyme induced by NaF plus $\mathrm{MgCl}_{2}$ were similar with respect to the requirement of $\mathrm{F}^{-}$, and had similar dose-response curves to $\mathrm{F}^{-}$(Fig. 4). However, for the requirement of $\mathrm{Mg}^{2+}$, dose-response curves for both processes were not coincident. (Figs. 5 and 6).

The turbidity change induced by $\mathrm{F}^{-}$and $\mathrm{Mg}^{++}$was reversed by triphospho-nucleotides (Table 2). The addition of CGTA decreased the turbidity due to $\mathrm{F}^{-}$plus $\mathrm{Mg}^{2+}$, but the time course was somewhat slower than that by triphospho-nucleotides. Therefore, the effect of triphospho-nucleotides on turbidity does not appear to be caused by removal of metal ions due to at chclating action of nucleotides on $\mathrm{Mg}^{2+}$ or other divalent cations. The preparation in which turbidity was increased by $\mathrm{F}^{-}$plus $\mathrm{Mg}^{*}{ }^{+}$or reversed by further incubation with ATP was gathered by centrifugation and was examined under electron microscopy with $\mathrm{OsO}_{4}$ stain or PTA (phospho-tungustic acid)-negative stain. However, no significant changes were observed on the membranes. We previously reported (19) that the interaction of fluorochrome, 2-p-toluidinylnaphthalene-6-sulfonate (TNS) with microsomes was changed by $\mathrm{F}^{-}$plus $\mathrm{Mg}^{2+}$ or ATP. The fluorescence of TNS was rapidly increased by $\mathrm{NaF}$ and $\mathrm{MgCl}_{2}$ and was seen to reverse to the original level with addition of ATP. The changes in fluorescence by $\mathrm{NaF}_{\text {plus }} \mathrm{MgCl}_{2}$ or ATP may be attributed to reversible changes in the membrane itself from a hydrophilic to a hydrophobic state.

The mechanism of the activation of adenylate cyclase by $\mathrm{F}^{-}$is unknown. The stimulatory effect of NaF on adenylate cyclase is nonspecific and the enzyme from all mammalian tissues can be stimulated. These observations suggest that NaF acts at a site common to all adenylate cyclases. Johnson and Sutherland (27) reported the following observations. Adenylate cyclase from the rat brain dispersed by detergents exhibited a relatively high specific activity and was inhibited by $\mathrm{NaF}$. When the dispersed cnzyme was re-aggregated by removing detergents, the stimulation of the activity by NaF was restored. Harwood and Rodbell (13) recently reported that $\mathrm{NaF}$ inhibited the hormonal activation of adenylate cyclase from rat adipocyte at temperatures below $25^{\circ} \mathrm{C}$. They suggested that $\mathrm{NaF}$ acts at some point on the pathway by which hormonal interaction with the receptor leads to an increase in the catalytic activity of the enzyme. NaF, as reported by Yoshida et al (28), has an inhibitory 
effect on $\mathrm{Na}^{+}, \mathrm{K}^{+}$-ATPase which exists in many species of microsomes, and the inhibitory effect of $\mathrm{NaF}$ on $\mathrm{Na}^{+}, \mathrm{K}^{+}$-ATPase is irreversible and the activity of $\mathrm{Na}^{+}, \mathrm{K}^{+}$-ATPase is not restored by washing with the buffer medium. These observations as well as the present results on turbidity change support the possibility that $\mathrm{NaF}$ may act on some component of membranes common to all species and therefore induce a change in a membranous environment. Adenylate cyclase which exists in a membrane as an integral component may conform to an active form by changes in a membranous environment surrounding the enzyme. The effect of ITP was remarkable on reversing the activity of adenylate cyclase enhanced by $\mathrm{NaF}$ and $\mathrm{MgCl}_{2}$ (Table 4). Recently, many workers have shown that GTP and its analog $[\mathrm{Gpp}(\mathrm{NH}) \mathrm{p}]$ enhance the response of adenylate cyclase to peptide hormones (e.g. glucagon and TSH), catecholamines and prostaglandins in different tissues (29-36). In some of these tissues, nucleotides other than GTP were also shown to have a similar, but less potent effect on adenylate cyclase activity. There are however, considerable differences in the relative potency of various nucleotides depending on tissues and hormones for stimulation. In the case of TSH-stimulated adenylate cyclase of thyroid membrane, ITP was demonstrated to be much more effective than GTP and other nucleotides (33). In contrast, a high concentration $\left(10^{-3} \mathrm{M}\right)$ of ITP had a potent inhibitory effect on $\mathrm{F}^{-}$-stimulated adenylate cyclase in this tissue, but GTP had little effect on the enzyme activity with $\mathrm{F}^{-}$.

There are a few reports $(33,35,36)$ concerning the effect of nucleotides on $\mathrm{F}^{-}$-stimulated adenylate cyclase. The present results on $\mathrm{F}^{-}$-stimulated adenylate cyclase of chick brain appear to be similar to results found with the thyroid. In studies on adenylate cyclase of the thyroid, however, the effects of nucleotides on the enzyme activity were examined by adding these nucleotides directly to the incubation mixtures for adenylate cyclase assay. In the present studies, the enzyme sample was preincubated with various nucleotides and then thoroughly washed with a large volume of buffer solution to remove the direct effect of these nucleotides on adenylate cyclase assay. Therefore, the effect of ITP in the present studies may be due to a different mechanism from that involved in the case of the thyroid.

The effect of ITP on $\mathrm{F}^{-}$-stimulated adenylate cyclase was observed only at high concentrations (Fig. 10). This effect of ITP however, was not caused by removal of metal ions from the sample due to chelating action of ITP on $\mathrm{Mg}^{2+}, \mathrm{Mn}^{2+}$ or $\mathrm{Ca}^{2+}$ which did have some effect on the enzyme activity, because the stability constants of complexes of ITP with these metal ions are almost the same as those of ATP and AMP with these ions.

The reversal of turbidity by ITP was a rapid process, preceeded to the decline in the enzyme activity elevated by $\mathrm{F}^{-}$. With respect to the reversing effect of ITP on both adenylate cyclase activity and membrane turbidity, both dose response curves were quite similar (Fig. 10). These observations support the possibility that ITP induces a reversal of structure change of the membrane due to $\mathrm{F}^{-}$and consequently may produce the activity change of adenylate cyclase. The reversal of the enzyme activity was observed, however, only with ITP among the various nucleotides which had the same potency on reversal of membrane turbidity (Table 4). This discrepancy remains to be elucidated. One possible explanation is as follows. The effects of nucleotides on membrane turbidity were determined only in 
the presence of nucleotides while adenylate cyclase was assayed after extensive washing of the samples which had been incubated with nucleotides. Nucleotides other than ITP may be washed away and only ITP may remain bound to the membrane preserving the membrane in a certain state. Other components in membranes may also be lost by extensive washing. This would result in an instability and unresponsiveness to re-exposure to $F^{-}$of the enzyme, of which activity was reversed by incubation with ITP.

We have not yet determined whether the effect of ITP on the enzyme activity and membrane turbidity may be accompanicd by phosphorylation of some conponents in the membrane. However, IDP and ADP wcre also partially effective for the cnzyme activity and membrane turbidity, respectively. Thus interaction of the nucleotide with the membrane appears to be an important process to induce its effects. Recently Najjar and his co-workers (14-16) reported that adenylate cyclase existed in an inhibited phospho- and activated dephospho-form, and a phospho-form was dephosphorylated by a membrane phosphoprotein phosphatase which was stimulated by $\mathrm{F}^{-}$, and that the dephospho-form was phosphorylated by a protein kinase. If we consider the present results in light of this hypothesis, there is the possibility that $\mathrm{F}^{-}$or ITP might induce a change in a membrane structure so that a membrane-phosphoprotein phosphatase or -protein kinase might act on phosphoor dephospho-residues of adenylate cyclase macromolecules.

To elucidate the mechanism of activity change of adenylate cyclase induced by $\mathrm{F}^{-}$and ITP and its relation to the change in turbidity, further studies are underway.

Acknowledgements: We are grateful to Dr. S. Uchida for calculation of free $\mathrm{Ca}^{-+}$ concentration by the method of Portzehl et al. (24). We also thank Mr. T. Ise for technical assistance with the electron microscopy. This work was supported in part by a grant for scientific research from the Ministry of Education, Japan.

\section{REFERENCES}

1) Rall. T.W. aNd Slitherlavi, E.W.: f. biol. Chem. 232, 1065 (1958)

2) Sutherland, E.W., Raj.l, T.W. and Menon, T. J. biol. Chem. 237, 1220 (1962)

3) Perkins, J.P.: Advances in Cyclic Nucleotide Research, Ediled by Grefngard, P. And RoBINsoN, G.A., Vol. III, p. I Raven Press, New York (1973)

4) Kornfgay, D. And Penningron, S.: Fluoride, 6, 19 (1973)

5) Robinson, G.A., Butcher, R.W. and Sutherland, E.W.: Cyclic AMP, p. 17, Academic Press, New York (1971)

6) Asakawa, T. And Yoshida, H.: Japan. J. Pharmacol. 23, S.91 (1973)

7) Birnhalmer, L., Pohl., S.L. And Rodmil.1, M.: J. biol. Chem. 247, 2038 (1972)

8) SChramu, M. AND NaIM, E.: J. biol. Chem. 245, 3225 (1970)

9) Pastan, I., Pricer, W. ani Biaydhettf-Mackie, J.: Melabolism 19, 809 (1970)

10) KFel.y, L.A. AND Koritz, S.B.: Biochim. Biophys. Acta 237, 141 (1971)

11) PerkiRS, J.P. AND MOORE, M.M.: J, biol. Chem, 246, 62 (1971)

12) Severson, D.L., Drummond, G.l. avo Sulakhe, P.V.: J. biol. Chem. 247, 2949 (1972)

13) Harwood, J.P. avo Ropbfil, ..: J. biol. Chem. 248, 4901 (1973)

14) Najuar, V.A. and Constaniopoulos, A.: Mol. Cell. Biochem. 2, 87 (1973)

15) Constantopoulos, A. AND NaJar, V.A.: Biochem. biophys. Res. Commun 53, 794 (1973)

16) Layne, P., Consianiopoulos, A. Judgr, J.F.X., Rauner, R. and Najar, V.A.: Biochem. biophys. Res. Commun. 53, 800 (1973)

17) Asakawa, T, Kawasaki, A. and Yoshida, H.: Bull. Japan. Neurochem. Soc. 9, S.17 (1970) 
18) Asakawa, T. and Yoshida, H.: Japal. J. Pharmacol. 21, 569 (1971)

19) Asakawa, T. and Yoshida, H. : Japan. I. Pharmacol. 22, S.82 (1972)

20) Asakawa, T. AND Yoshidd, H.: Fotrth Intermational Meeing of the International Society for Newochemistry, Tokyo, Abs. p. 219 (1973)

21) Krishna, G., Wliss, B. and Bronit, B.B.: I. Phamacol. exp. Ther. 163, 379 (1968)

22) Bray, G.A.: Analyt. Biochem. 1, 279 (1960)

23) Lowry, O.H., Rosbbrougih, N.J., Farr, A.L. and Randall, R.J. : J. biol. Chem. 193, 265 (1951)

24) Poktzfhi, H., Caldwell, P.C. and Rlegg, I.C.: Biochim. Biophys. Acta 79, 581 (1964)

25) Bradilam, I.S., Hot.T. D.A. Axd Sims, M.: Biochint. Biophys. Acta 201, 250 (1970)

26) Bradham, L.S.: Biochim. Biophys. Acta 276, 434 (1972)

27) Johnson, R.A. a.nd SUTHERLAND. E.W.: J. hiol. Chem. 248. 5114 (1973)

28) Yoshida, H. Nagat, K., Kame, M. and Nakagawa, Y.: Biochim. Biophys. Acta 150, 162 $(1968)$

29) Rodbell., M.. Krans, H. M.J., Pohli, S.I. and Bir.halimer, L.: J. biol. Chem, 246, 1872 (1971)

30) Rodbell, M. Birnbaumfr, I.., Pohi. S.L. and Krans, H. M.J.: I. hiol. Chem. 246, 1877 (1971)

31) Goldfine, i.D., Roth, J. and Birnbaumer L.: J, biol. Chom. 247, 1211 (1972)

32) Krishna G., Harwood, J.P., Brrber, A.J., and Jamieson, G.A.: I. biol. Chem. 247, 2253 (1972)

33) WOLfF, J. AND GOOK, G.H.: J. biol. Chem. 248, 350 (1973)

34) Londos, C., Salomon, Y., Liv, M.C., Harwood, J.P., Schramm, M. Wolft, F. and Rodiell, M.: Proc. natn. Acad. Sci. U.S.A. 71, 3087 (1974)

35) Dr.try, D.J. AND Howtll, S.I.: Biochim. Biophys Acta 329, 17 (1973)

36) Londos, C. And Rodithl, M.: J. biol. Chem. 250, 3459 (1975) 